\title{
Calorie Restriction: The Natural Way of Slowing Down Aging
}

\section{Andromeda M. Nauli*, Yuxi Sun and Forrest J. Longway}

Department of Health Sciences, College of Public Health, East Tennessee State University, Johnson City, TN 37614, USA

\section{Non-Primate Studies}

Calorie restriction, a practice of reducing calorie intake without malnutrition, is probably one of the best ways to slow down aging. Studies have shown that calorie restriction could, in fact, increase the mean and maximal life span of many species, such as yeast, fish, mice, hamsters, and dogs [1]. The underlying mechanism of this "anti-aging" effect remains unclear. It is possible that the reduction of body fat, reduction in oxidative damage, and improved insulin sensitivity are all key contributors to the extended life span in mammals.

\section{Nonhuman Primate Studies}

Although its effect on life span in primates has not yet been confirmed, calorie restriction in rhesus monkeys reduced the risk of T2DM, cardiovascular diseases, and cancer [2]. The studies, which are still currently in progress, reveal that calorie restriction leads to many appealing physiological effects, including reduced body fat, slower rate of sarcopenia, increased insulin sensitivity and glucose tolerance. Since obesity is a predisposing factor of T2DM, it is unclear at the moment if the insulin sensitivity and glucose tolerance effect is mainly the results of the reduced body fat [3].

\section{Human Studies}

Many of the beneficial effects of calorie restriction have also been reported in humans. Calorie-restricted individuals displayed desirable plasma lipid profile, i.e., reduced LDL-cholesterol, reduced total cholesterol/HDL ratio, and reduced triglycerides [4,5]. They also had improved insulin sensitivity [6]. In addition, epidemiological data show that the inhabitants of the Okinawa Island (Japan), who consumed $1785 \mathrm{kcal} /$ day, had lower mortality rates from coronary heart disease and cancer [7]. Okinawa is known for its relatively high percentage of centenarians, and it was estimated that they consumed $14 \%$ less calorie than the mainland Japanese. However, since it was an epidemiologic study, other factors could also contribute to the longevity of the Okinawans, such as their higher consumption of natural antioxidants and/or lower consumption of protein.

The cancer-protective effect of calorie restriction seems to be mediated by IGF-1, as suggested by an elegant rodent study in which the inhibition of cancer cell proliferation by calorie restriction could be abolished by normalizing the reduced serum GH/IGF-1 level [8]. In humans, calorie restriction did not seem to change serum IGF-1 level, but moderate protein restriction could reduce its level [9]. These studies suggest that it may be the reduction of protein, and not calorie per se, that is responsible for the anticancer effect in humans [7].

\section{Future Directions}

Calorie restriction remains to be one of the best ways to slow down aging. Studies using human subjects are challenging due to their long duration and strict adherence to calorie intake. As mentioned, epidemiologic studies are often informative but not conclusive. Several primate studies, which are still in progress, have shown great promise so far.

In summary, calorie restriction results in many physiological effects that are characteristics of youthful stage, including improved insulin sensitivity, improved plasma lipid profile, reduced body adiposity, and reduced oxidative damage. Its anticancer effect in humans is probably due to the moderate reduction in protein intake as part of the calorierestricted regimen. More basic science studies are certainly needed to dissect the underlying mechanisms of the "anti-aging" effect of calorie restriction. Our hope is that a better health can be achieved from these studies.

\section{Acknowledgement}

A.M. Nauli was supported by RDC Major and Interdisciplinary Grants (ETSU).

\section{References}

1. Masoro EJ (2005) Overview of caloric restriction and ageing. Mech Ageing Dev 126: 913-922.

2. Kemnitz JW (2011) Calorie restriction and aging in nonhuman primates. ILAR J 52: 66-77.

3. Nauli AM (2012) Pancreatic Disorders in Cancer, Diabetes, and Obesity Pancreat Disorders Ther 2: e126.

4. Fontana L, Villareal DT, Weiss EP, Racette SB, Steger-May K, et al. (2007) Calorie restriction or exercise: effects on coronary heart disease risk factors. A randomized, controlled trial. Am J Physiol Endocrinol Metab 293: 197-202.

5. Lefevre M, Redman LM, Heilbronn LK, Smith JV, Martin CK, et al. (2009) Caloric restriction alone and with exercise improves CVD risk in healthy nonobese individuals. Atherosclerosis 203: 206-213.

6. Lim EL, Hollingsworth KG, Aribisala BS, Chen MJ, Mathers JC, et al. (2011) Reversal of type 2 diabetes: normalisation of beta cell function in association with decreased pancreas and liver triacylglycerol. Diabetologia 54: 2506-2514.

7. Willcox BJ, Willcox DC, Todoriki H, Fujiyoshi A, Yano K, et al. (2007) Caloric restriction, the traditional Okinawan diet, and healthy aging: the diet of the world's longest-lived people and its potential impact on morbidity and life span. Ann N Y Acad Sci 1114: 434-455.

8. Hursting SD, Switzer BR, French JE, Kari FW (1993) The growth hormone: insulin-like growth factor 1 axis is a mediator of diet restriction-induced inhibition of mononuclear cell leukemia in Fischer rats. Cancer Res 53: 2750-2757.

9. Fontana L, Weiss EP, Villareal DT, Klein S, Holloszy JO (2008) Long-term effects of calorie or protein restriction on serum IGF-1 and IGFBP-3 concentration in humans. Aging Cell 7: 681-687.

*Corresponding author: Andromeda M. Nauli, East Tennessee State University, Box 70673, Johnson City, TN 37614-1709, USA, Tel: (423) 439-6186; Fax: (423) 439-4562; E-mail: naulia@etsu.edu

Received November 01, 2012; Accepted November 03, 2012; Published November 05, 2012

Citation: Nauli AM, Sun Y, Longway FJ (2012) Calorie Restriction: The Natural Way of Slowing Down Aging. J Biosafety Health Educ 1:e103. doi:10.4172/23320893.1000e103

Copyright: $\odot 2012$ Nauli AM, et al. This is an open-access article distributed under the terms of the Creative Commons Attribution License, which permits unrestricted use, distribution, and reproduction in any medium, provided the original author and source are credited. 